\title{
Avian richness of the Basanta Protected Forest, far-western lowland Nepal: Implication for conservation
}

\section{Hiru Lal Dangaura ${ }^{1}$ (D) | Naresh Pandey ${ }^{2^{*}}$ (D) | Dhirendra Bahadur Chand ${ }^{3}$ (D) Krishna Prasad Bhusal $^{1}$ (i)}

${ }^{1}$ Bird Conservation Nepal, Lazimpat, Kathmandu

${ }^{2}$ Central Department of Zoology, Institute of Science and Technology, Tribhuvan University, Kathmandu

${ }^{3}$ Wildlife Research Center, Dhangadhi, Nepal

*Correspondence: pandeynaresh25@gmail.com

Received: 25 September 2020 | Revised: 14 November 2020 | Accepted: 18 November 2020

\begin{abstract}
Birds are important components of biodiversity and acts as an indicator of habitat quality, productivity and stability. This study aimed to document species richness and assess the temporal distribution pattern of globally threatened bird species in the Basanta Protected Forest (BPF), one of the largest corridor forests which connects Dudhwa National Park (India) with protected areas of western lowland Nepal. During study period of ten years from 2010 to 2019 , a total of 381 bird species from 78 families of 19 orders were recorded. Order Passeriformes had the highest species richness $(n=180)$ followed by order Accipitriformes and Charadriiformes. Among the families, the family Muscicapidae had the highest species richness $(n=31)$, followed by Accipitridae and Anatidae. Majority of bird recorded were forest bird followed by wetland and farmland bird species. Fifteen globally threatened species like red-headed vulture (Sarcogyps calvus), white-rumped vulture (Gyps bengalensis), slender-billed vulture (Gyps tenuirostris), steppe eagle (Aquila nipalensis) and Egyptian vulture (Neophron percnopterus) were recorded in the BPF. Extensive avian survey in the BPF is important for further exploration of avian community along with its driving factors, which might play a crucial role in developing baseline information and implementing conservation implications.
\end{abstract}

Keywords: Bird community; Ghodaghodi; Forest; Vantage points; Passeriformes

\section{1 | Introduction}

Birds have been associated with forests as long as there have been birds (Sereno \& Chenggang 1992). From the time of origin, birds have occupied diversified habitat and foraging strategies compared to other vertebrates (Naish 2014). Birds are good indicators of habitat quality, productivity and stability (Vallecillo et al. 2016), because they respond quickly to habitat change. Forest being one of the major habitats of bird species provides nesting (Bakermans et al. 2012), wintering sites (Wunderle Jr \& Waide 1993, Bauer \& Hoye 2014) and thermal refugia (Dawson et al. 2005, Seavy 2006). And most important, forest is the source of shelter and sustenance for majority of bird species (Jordano 1995, Sekercioglu et al. 2004, Kissling et al. 2012).

Highest number of bird species are found in tropical and subtropical forests in Southeast Asia and declines towards the pole (Newton 2003). A large variety of species ranging from least concerned to threatened species are found in the forest. Majority of the threatened bird species are found in forest (BirdLife International 2017). The anthropogenic pressure has negatively affected the forest and ultimately decreases the overall species richness (Reijnen et al. 1995, Halfwerk et al. 2011). Few decades back, it was estimated that if the deforestation and habitat degradation persisted, about 20 percent of the tropical forest by the year 2020 and more than 50 percent of the same by the year 2024 is likely to be lost (Wilson 1989). And recent studies carried on tropical forest of Brazil and Southeast Asia have concluded that biodiversity declines with habitat loss (Barlow et al. 2016, Symes et al. 2018). Studies from around the globe have found that habitat specialist bird species are most susceptible to forest disturbances (Arcilla et al. 2015, Pavlacky Jr et al. 2015, Asefa et al. 2017)

Basanta Protected Forest (BPF) is a part of Terai Arc Landscape (TAL), a Global 200 Ecoregion which is categorized as 
critical/endangered (Olson \& Dinerstein 2002). Forest corridor link protected areas providing refugee for wildlife population. The BPF link Sukhlaphata National Park and Bardia National Park of Nepal with Dudhwa National Park in India through the forest of Churia foothills and is frequently used by globally important mammalian species like tigers, elephants and rhinocerous. Ghodagodi lake, a globally known Ramsar site lies within Basanta forest, which is one of the major ecological importance of this forest. Having significant ecological value, this forest faces potetinal threats of excessive grazing, poisoning, encroachment, infrastructure development, eutrophication and Chure degradation (Gurung et al. 2018). Although numerous studies have been done focusing on the Ghodaghodi wetland, proper documentation of species richness in the entire BPF is yet lacks. Knowing the importance of adjacent forest in wetland ecosystem conservation and management. This study aimed to document species richness of entire BPF and assess the temporal distribution pattern of globally threatened species.

\section{2 | Materials and methods}

\subsection{Study area}

Basanta Protected Forest (BPF) with a total area of 83438.9 hectors lies in Kailali district. It occupies about

25.3 percent of total area of district. Twenty-seven lakes including largest natural lake cluster of Terai region commonly known as Ghodaghodi ramsar site lies within this protected forest. This protected forest area is composed of four different types of forests: Chir-pine forest, Chir-pine broad-leaved forest, Hill sal forest and towards terai plains there is lower tropical sal and mixed broad-leaved forest. Dominant vegetation found are sal (Shorea robusta), asna or saj (Terminalia alata), simal (Bombax ceiba), khair (Acacia catechu) and so on. Along with this, two species- globally vulnerable satisal (Dalbergia latifolia) and nationally threatened vijaysal (Pterocarpus marsupium) were also recorded. Not only flora, this forest is also rich in faunal diversity. Globally threatened species like tiger (Panthera tigris), Asian elephant (Elephas maximus), clouded leopard (Neofelis nebulosa), smooth-coated otter (Lutra perpiscillata), red-crowned roofed turtle (Kachuga kachuga), etc have been recorded (Bista \& Shah 2010, Kafle 2009, Shrestha et al. 2014).

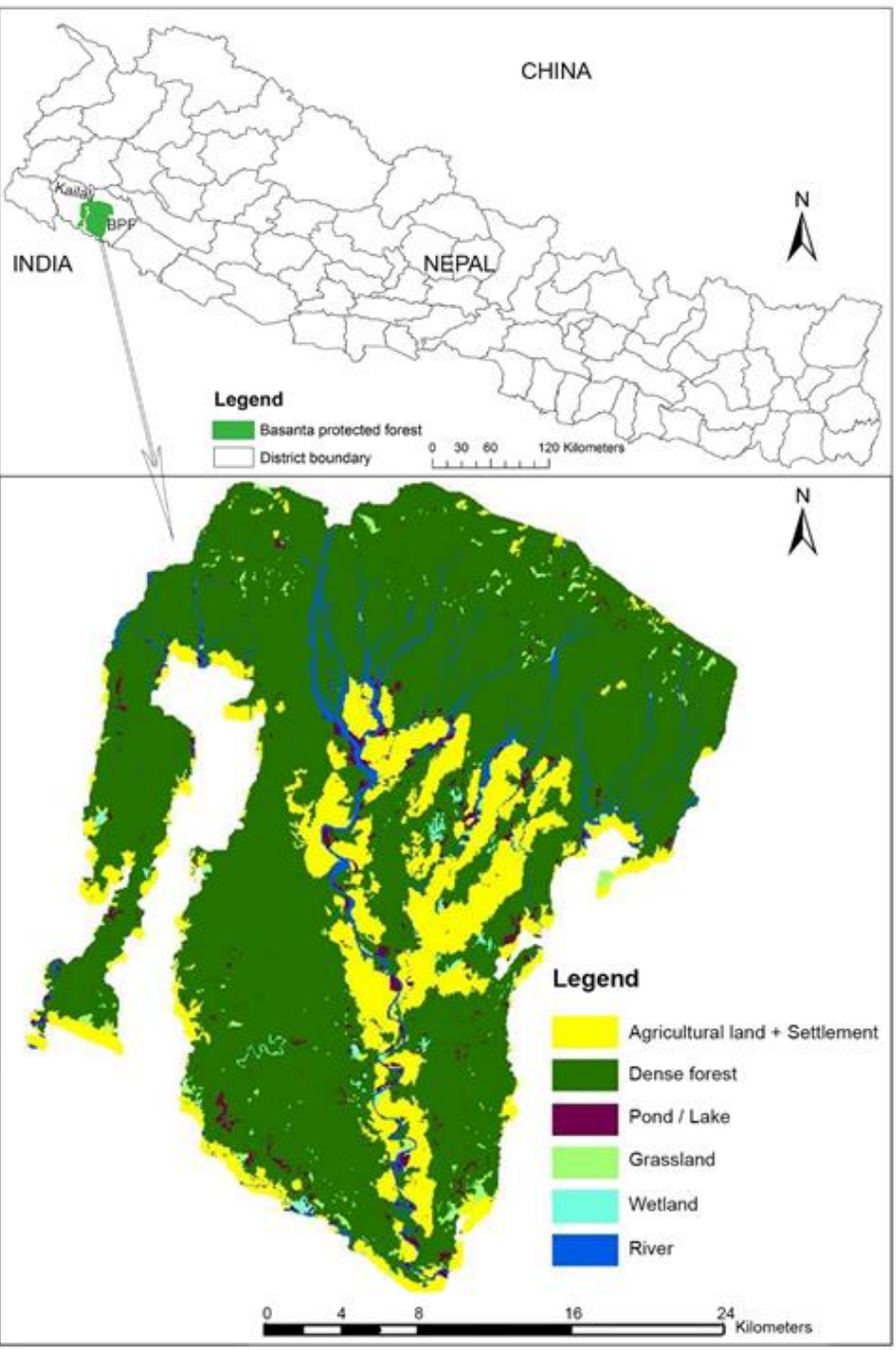

Figure 1. Map of the Basanta Protected Forest showing the land-use categories

\section{$2.2 \mid$ Bird survey}

Different bird observation techniques were employed during study. For wetland birds, point count from vantage point was employed, vantage points were selected to cover maximum sighting distance, but not more than $1 \mathrm{~km}$. In each vantage point, 15 to 20 minutes time was spent tending towards as shorter time period as possible to avoid multiple counting of a single individual of the bird species. And for terrestrial birds, point count method (Bibby et al. 2000) was used. Birds observed and heard within $20 \mathrm{~m}$ radius were recorded from a fixed point. The period of observation for a point varied based on habitat. About 20 minutes in the dense forest to detect rare and inconspicuous species (Dos Anjos \& Bocon 1999, Pandey et al. 2020) and 10 minutes in an open area like cultivation/farmland. Bushnell Falcon $10^{*} 50$ wideangle binoculars were used. Most of the data were recorded opportunistically by the first author for ten years. Opportunistic 
data have been used previously for species occurrence at large geographic and temporal scale (Devictor et al. 2010). Many previous studies from avian taxa have proved similar results found from large volume of opportunistic data to those of formal bird count surveys when examining spatial and temporal patterns of bird occurrences (Munson et al. 2010, Walker \& Taylor 2017). For wetland birds and threatened species field surveys were done in summer and winter seasons. The field books-'Birds of Nepal' (in Nepali) (Grimmet et al. 2003) and 'Birds of Nepal' (Grimmett et al. 2016) were used for the identification of birds.

\section{3 | Data analysis}

The collected data from the field survey were at first entered into an excel datasheet. Observed birds were classified into four feeding guilds- carnivorous, frugivorous, omnivorous and insectivorous, based on the diet descriptions available in (Sundar \& Subramanya 2010, Grimmett et al. 2016). Population trend of globally threatened birds were analysed for last 10 years. All the graphs and plots were drawn using excel.

\section{3 | Results}

\subsection{Avian richness of the BPF}

A total of 381 bird species was recorded representing 19 orders and 78 families. During study, conservation priority species (i.e. globally threatened species, nationally threatened species and bird species listed on CITES) were also recorded. Passeriformes (180) order was found dominant and least numbers of bird species were recorded from order Podicipediformes (Fig. 2).
In case of family, highest number of species were recorded from family Muscicapidae followed by Accipitridae and lowest was recorded form families- Anhingidae, Burhinidae, Recurvirostridae and so on.

\section{2 | Species richness in different habitat types}

Among 381 bird species, 76 species of wetland birds and 305 species of terrestrial birds were recorded. In case of terrestrial birds, 46 species of agricultural/farmland birds and 259 species of forest birds were recorded (Fig. 3).



Figure 3. Species richness in different habitat types of the BPF.

\section{3 | Species richness in different feeding guilds}

Concerning feeding guilds, highest number of Insectivorous species (192) were recorded followed by Omnivorous (75) and lowest number of Granivorous (6) (Fig. 4).

\section{4 | Conservation priority birds of the BPF}

During the study, number of conservation priority species were found. A total of 15 globally threatened species, 53 nationally threatened species and 58 CITES enlisted bird species were recorded from study area (Fig. 5) (Annex 1). Globally threatened species like redheaded vulture (Sarcogyps calvus), white-rumped vulture (Gyps bengalensis), slender-billed vulture (Gyps tenuirostris), Asian woolly neck (Ciconia episcopus) and so on were recorded (Table 1) (Fig. 6).

Figure 2. Number of bird species in different orders observed in the BPF, Kailali. 


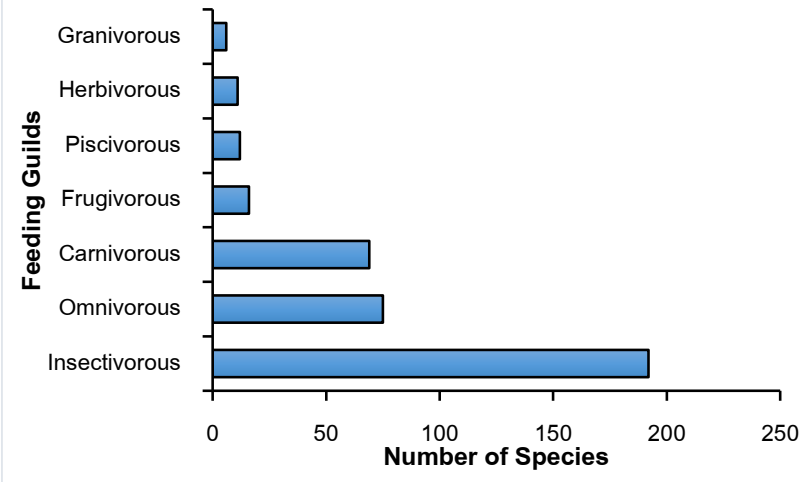

Figure 4. Species richness in different feeding guilds of birds observed in BPF, Kailali.

To assess the change in temporal pattern of globally threatened species, most frequently recorded GTS were plotted year wise (Fig. 7). The irregular temporal distribution pattern might be due to inconsistent time, season and survey effort for some globally threatened species. Globally threatened species like, swamp francolin, lesser adjutant, red-headed vulture, slender-billed vulture, steppe eagle, grey-crowned prinia and Finn's weaver were recorded once in study period of 10 years. Vulnerable species-sarus crane has irregular temporal distribution patterns, it was recorded in year 2010-11 and did not record for 7 years. supporting a high diversity of flora and fauna. However, the avian community of entire Basanata forest is still unexplored. Therefore, this study aimed to document species richness of entire forest and assess the temporal distribution pattern of globally

Table 1. List of globally threatened bird species recorded in the BPF, Kailali

\begin{tabular}{|l|l|l|l|}
\hline SN & English name & Scientific name & IUCN Categories \\
\hline 1 & Red-headed Vulture & Sarcogyps calvus & \multirow{2}{*}{$\begin{array}{c}\text { Cnitically } \\
\text { Endangered }\end{array}$} \\
\hline 2 & White-rumped Vulture & Gyps bengalensis & \multirow{2}{*}{ Endangered } \\
\hline 3 & Slender-billed Vulture & Gyps tenuirostris & \\
\hline 4 & Steppe Eagle & Aquila nipalensis & \multirow{2}{*}{ Vulnerable } \\
\hline 5 & Egyptian Vulture & Neophron percnopterus & \\
\hline 6 & Swamp Francolin & Francolinus gularis & \\
\hline 7 & Common Pochard & Aythya ferina & \\
\hline 8 & Sarus Crane & Antigone Antigone & \\
\hline 9 & Lesser Adjutant & Leptoptilos javanicus & \\
\hline 10 & Asian Woollyneck & Ciconia episcopus & \\
\hline 11 & Indian Spotted Eagle & Clanga hastate & \\
\hline 12 & Great Hornbill & Buceros bicornis & \\
\hline 13 & Great Slaty Woodpecker & Mulleripicus pulverulentus & \\
\hline 14 & Grey-crowned Prinia & Prinia cinereocapilla & \\
\hline 15 & Finn's Weaver & Ploceus megarhynchus & \\
\hline & & & \\
\hline
\end{tabular}

threatened species in Basanta forest.

\subsection{Avian richness of the BPF}

This study recorded a total of 381 species of birds belonging to 19 orders representing 78 families. Order Passeriformes and family Muscicapidae was found dominant among the avian community, which is similar to other studies in birds (Inskipp \& Inskipp 2003, Adhikari et al. 2019, Pandey et al. 2020). We observed that insectivorous form is the most speciesrich feeding guild in the Basanta forest, which is consistent with many other studies in birds (Katuwal et al. 2016, Pandey et al. 2020). Highly diverse avian community of the study area might be due to greater habitat complexity (Pan et al. 2016, Hu et al. 2018). Lakes

Figure 5. Species richness of conservation priority observed in BPF, Kailali.

Later, it was again recorded in year 2019-20.

\section{4 | Discussion}

Basanta forest is one of ecologically important forest of western Terai, which have a globally important Ghodagodi Ramsar site within. Climatic zonation, diverse habitat and connectivity with Dudhwa National Park of India might be the reason behind complex, riverine habitat, forest habitat with different forest types like chir-pine forest, chir-pine broad-leaved forest, Hill sal forest, and tropical sal and mixed broadleaved forest have created habitat heterogeneity. Along with that, different land-use types include agricultural land, human settlement area, shrublands, grasslands and some barren area have supported wide habitat, 
shelter and resources to the species (Canterbury et al. 2000, Schaub et al. 2010, Ferger et al. 2014, Crosby et al. 2015). In agricultural land, bare ground has been observed to be an important component of habitat for especially ground foraging insectivorous bird (Schaub et al. 2010), and some granivorous species (Moorcroft et al. 2002).

\section{2 | Globally threatened birds in the BPF}

Altogether 38 bird species from Nepal were declared as globally threatened species (BirdLife International 2020). Among that, we recorded 15 globally threatened (three Critically Endangered, two Endangered and ten Vulnerable) species in BPF alone. In national context, 168 bird species were assessed as nationally threatened species which includes 68 Critically Endangered species, 38 Endangered species and 62 Vulnerable species (Inskipp et al. 2017). A total of 53 nationally threatened (thirteen Critically Endangered, fourteen Endangered and twenty-six Vulnerable) species were recorded from this forest.

In global scenario, risk of extinction of birds is increasing day by day (White \& Bennett 2015). With an increase in population, stress on forest increases and ultimately results in habitat destruction and degradation. Encroachment of forest area by local inhabitants, poaching and expansion of Mahendra highway are examples of anthropogenic actions found in the study area. Alternation of

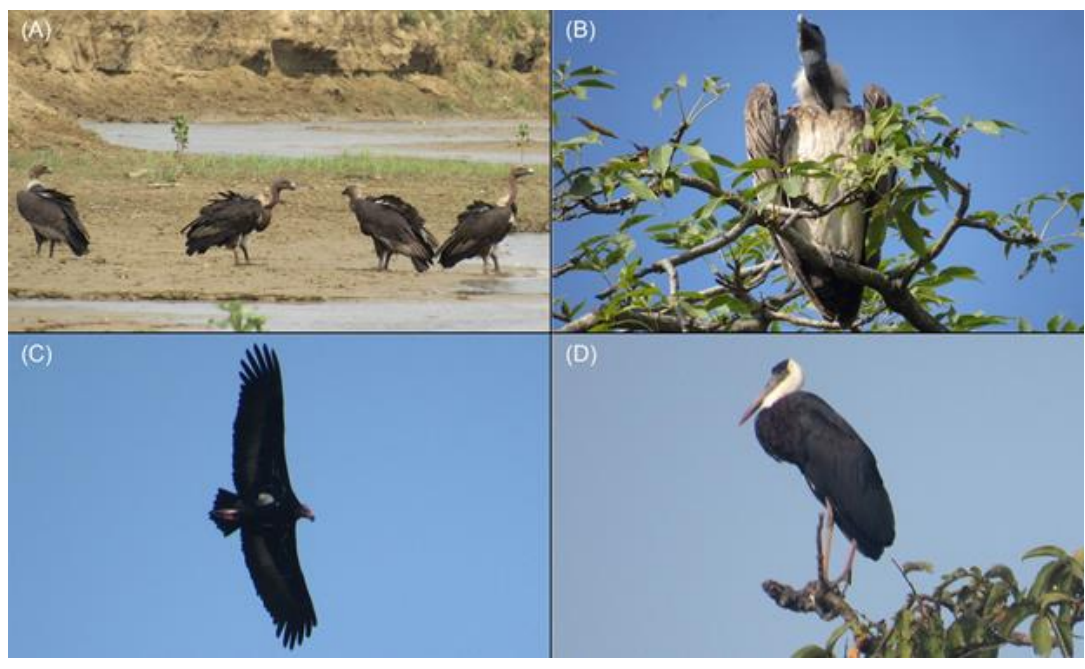

Figure 6. Some globally threatened birds observed in the Basanta Protected forest. A, White-rumped vulture (Gyps bengalensis); B, Slender-billed vulture (Gyps tenuirostris); C, Red-headed vulture (Sarcogyps calvus); D, Asian woollyneck (Ciconia episcopus) (Photos by: Hiru Lal Dangaura). vegetation structure and habitat fragmentation through forest degradation and deforestation are among the main threats affecting biodiversity (Sekercioglu 2002, Heikkinen et al. 2004, Chace \& Walsh 2006). In many previous studies, it was found many forest specialist species are negatively affected by forest disturbance and have disappeared from some heavily transformed forests (Sekercioglu 2002, Gove et al. 2008). And, in contrast, habitat generalist species can positively exploit habitat changes induced by disturbance and better adapted to open habitats (Sekercioglu 2002, Chace \& Walsh 2006).

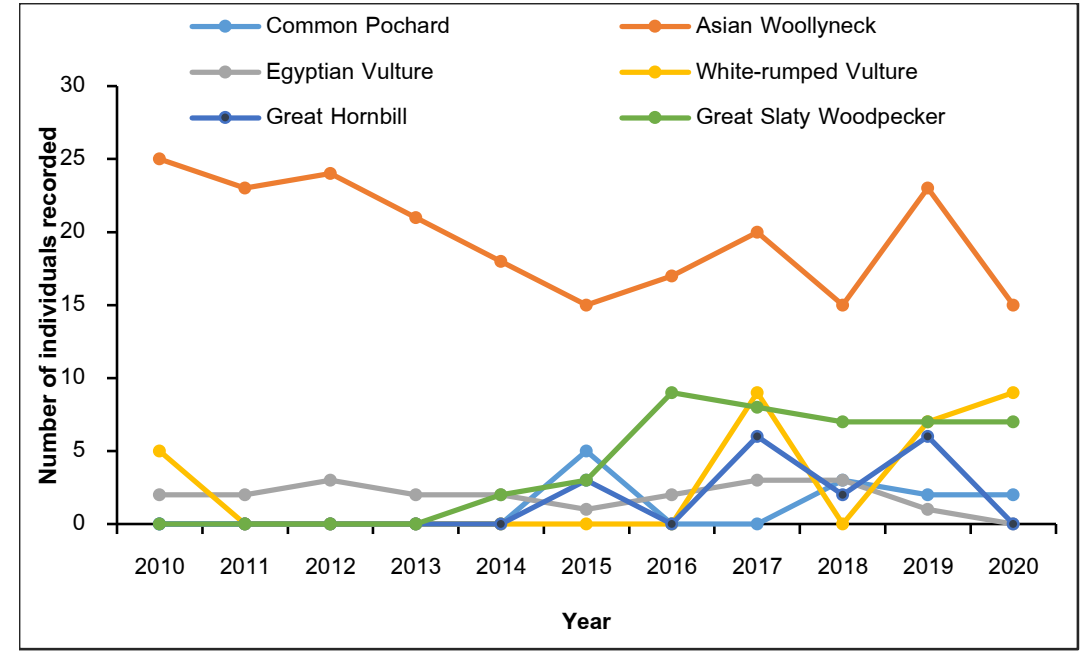

Figure 7. Temporal distribution of some globally threatened species observed in BPF, Kailali.

\section{3 | Conservation implication}

Basanta forest is one of the largest corridor forests which connects Dudhwa National Park (India) with western lowland protected areas of Nepal. Movement of flagship species like tiger (Panthera tigris) and elephant (Elephas maximus) occurs in this forest. Corridors are designed to maintain connectivity among fragmented resources and are modern approaches for heterogeneous landscape conservation. Connectivity among habitat patches are crucial for conservation and to facilitate movements between fragmented resources (Taylor et al. 1993, Hess \& Fischer 2001).

Another important aspect of this forest is Ghodaghodi Ramsar site, largest natural wetland of terai lies within this forest. It is one of IBAs which harbours many wetland birds. The values of wetland ecosystem service ranks 
first among all kinds of ecosystem (Costanza et al. 1997) and it is due to irreplaceable role in maintaining the global hydrological cycle, regulating the global climate, safeguarding human welfare and protecting the ecosystem diversity (Bureau 2006, Hu et al. 2017). Numbers of globally and nationally threatened species along with other bird species were found in this forest. Not only for avian fauna, it is equally important for other taxa too. So, conservation of this entire forest area is very important. Numerous studies were conducted focusing on Ghodaghodi Ramsar site. Despite being ecologically important, very few extensive surveys in the entire forest is carried till date. Anthropogenic factors were found affecting forest area and ultimately bird community. Therefore, regular monitoring of habitat change and bird community should be done to counter anthropogenic changes.

\section{5 | Conclusions}

The study found that entire BPF has diverse avian community and is home for large number of bird species including globally and nationally threatened species. High diverse community is due to habitat heterogeneity, diverse forest and landuse types and connectivity between protected areas. Declined occurrence of globally threatened species such as red-headed vulture, whiterumped vulture, steppe eagle, swamp francolin, Asian woollyneck etc, might be due to anthropogenic factors like encroachment, road expansion, poaching and eutrophication. Therefore, a detailed study assessing the factors affecting the avian richness in BPF is warranted.

\section{Acknowledgements}

We would like to acknowledge Mr. Daya Ram Chaudhary, Bird Conservation Network; Mr Puskal Bahadur Bam, Basanta Protected Forest Council; Bijay Raj Shrestha and Sunita Chaudhary for their support during field work. We would also like to thank Mr. Rajiv Chaudhary, Division Forest Office, Pahalmanpur for providing information during manuscript preparation.

\section{Authors' contributions}

Dangaura, H. L. performed field data collection. Pandey, N., Chand, D. B. and Bhusal, K. P. analysed the data and prepared manuscript. All authors contributed in manuscript improvements and approved for submission.

\section{Conflicts of interest}

Authors declare no conflict of interest.

\section{ORCID}

Hiru Lal Dangaura (iD https://orcid.org/0000-0003-3394-5978

Naresh Pandey (D) https://orcid.org/0000-0002-0599-648X

Dhirendra Bahadur Chand iD https://orcid.org/0000-0003-0474-9716

Krishna Prasad Bhusal iD https://orcid.org/0000-0002-2259-1513

\section{References}

Adhikari, J. N., Bhattarai, B. P. and Thapa, T. B. 2019. Factors affecting diversity and distribution of threatened birds in Chitwan National Park, Nepal. Journal of Threatened Taxa 11:13511-13522. https://doi.org/10.11609/jott.4137.11.5.13511-13522

Arcilla, N., Holbech, L. H. and O'Donnell, S. 2015. Severe declines of understory birds follow illegal logging in Upper Guinea forests of Ghana, West Africa. Biological Conservation 188:41-49. https://doi.org/10.1016/j.biocon.2015.02.010

Asefa, A., Davies, A. B., McKechnie, A. E., Kinahan, A. A. and van Rensburg, B. J. 2017. Effects of anthropogenic disturbance on bird diversity in Ethiopian montane forests. The Condor: Ornithological Applications 119:416-430. https://doi.org/10.1650/CONDOR-16-81.1

Bakermans, M. H., Rodewald, A. D. and Vitz, A. C. 2012. Influence of forest structure on density and nest success of mature forest birds in managed landscapes. The Journal of Wildlife Management 76:1225-1234. https://doi.org/10.1002/jwmg.349

Barlow, J., Lennox, G. D., Ferreira, J., Berenguer, E., Lees, A. C., Mac Nally, R., et al. 2016. Anthropogenic disturbance in tropical forests can double biodiversity loss from deforestation. nature 535:144-147. https://doi.org/10.1038/nature18326

Bauer, S. and Hoye, B. J. 2014. Migratory animals couple biodiversity and ecosystem functioning worldwide. Science 344 . https://doi.org/10.1126/science.1242552

Bibby, C. J., Burgess, N. D., Hill, D. A. and Mustoe, S. 2000. Bird census techniques. Academic Press, USA, p 302.

BirdLife International 2017. Threatened birds occur in all habitats, but the majority are found in forest. Retrieved 25 September 2020, Retrieved from http://www.birdlife.org.

BirdLife International 2020. Country profile: Nepal. Retrieved 25 September 2020, Retrieved from: http://www.birdlife.org/datazone/country/nepal.

Bista, D. and Shah, K. 2010. Diversity and Status of the Turtles in Ghodaghodi Lake Area, Kailali district, Far West Nepal. Journal of Natural History Museum 25:366-373. 
Bureau, R. C. 2006. The Ramsar Convention Manual: A Guide to the Convention on Wetlands, Ramsar, Iran, 1971. Ramsar Convention Bureau.

Canterbury, G. E., Martin, T. E., Petit, D. R., Petit, L. J. and Bradford, D. F. 2000. Bird communities and habitat as ecological indicators of forest condition in regional monitoring. Conservation Biology 14:544-558. https://doi.org/10.1046/j.1523-1739.2000.98235.x

Chace, J. F. and Walsh, J. 2006. Urban effect on native avifauna: a review. Landscape and Urban Planning 74:46-69. https://doi.org/10.1016/j.landurbplan.2004.08.007

Costanza, R., d'Arge, R., De Groot, R., Farber, S., Grasso, M., Hannon, B., et al. 1997. The value of the world's ecosystem services and natural capital. Nature 387:253-260. https://doi.org/https://doi.org/10.1038/387253a0

Crosby, A. D., Elmore, R. D., Leslie Jr, D. M. and Will, R. E. 2015. Looking beyond rare species as umbrella species: Northern Bobwhites (Colinus virginianus) and conservation of grassland and shrubland birds. Biological Conservation 186:233-240. https://doi.org/https://doi.org/10.1016/j.biocon.2015.03.018.

Dawson, R. D., Lawrie, C. C. and O'Brien, E. L. 2005. The importance of microclimate variation in determining size, growth and survival of avian offspring: experimental evidence from a cavity nesting passerine. Oecologia 144:499-507. https://doi.org/https://doi.org/10.1007/s00442-005-0075-7

Devictor, V., Whittaker, R. J. and Beltrame, C. 2010. Beyond scarcity: citizen science programmes as useful tools for conservation biogeography. Diversity and Distributions 16:354-362. https://doi.org/10.1111/j.1472-4642.2009.00615.x

os Anjos, L. and Bocon, R. 1999. Bird communities in natural forest patches in southern Brazil. The Wilson Bulletin 111:397-414. https://doi.org/10.2307/4164105

Ferger, S. W., Schleuning, M., Hemp, A., Howell, K. M. and BöhningGaese, K. 2014. Food resources and vegetation structure mediate climatic effects on species richness of birds. Global Ecology and Biogeography 23:541-549. https://doi.org/10.1111/geb.12151.

Gove, A. D., Hylander, K., Nemomisa, S. and Shimelis, A. 2008. Ethiopian coffee cultivation-Implications for bird conservation and environmental certification. Conservation Letters 1:208-216. https://doi.org/10.1111/j.1755-263X.2008.00033.x.

Grimmet, R., Inskipp, C., Inskipp, T. and Baral, H. S. 2003. Nepalka charaharu. Bird Conservation Nepal.

Grimmett, R., Inskipp, C., Inskipp, T. and Baral, H. S. 2016. Birds of Nepal. Bloomsbury Publishing, UK, p 386.

Gurung, B., Jnawali, S. R., Dhakal, T., Bhattarai, B., Thapa, G. J. and Wikramanayake, E. 2018. Participatory threat assessment of two major wildlife corridors in the terai arc landscape. Parks 24:97. https://doi.org/10.2305/IUCN.CH.2018.PARKS-24-1.en

Halfwerk, W., Holleman, L. J., Lessells, C. M. and Slabbekoorn, H. 2011. Negative impact of traffic noise on avian reproductive success. Journal of Applied Ecology 48:210-219. https://doi.org/10.1111/j.1365-2664.2010.01914.x

Heikkinen, R. K., Luoto, M., Virkkala, R. and Rainio, K. 2004. Effects of habitat cover, landscape structure and spatial variables on the abundance of birds in an agricultural-forest mosaic. Journal of Applied Ecology 41:824-835. https://doi.org/10.1111/j.00218901.2004.00938.x

Hess, G. R. and Fischer, R. A. 2001. Communicating clearly about conservation corridors. Landscape and Urban Planning 55:195208. https://doi.org/10.1016/S0169-2046(01)00155-4

Hu, S., Niu, Z., Chen, Y., Li, L. and Zhang, H. 2017. Global wetlands: Potential distribution, wetland loss, and status. Science of the Total Environment 586:319-327.

https://doi.org/10.1016/j.scitotenv.2017.02.001

Hu, Y., Ding, Z., Jiang, Z., Quan, Q., Guo, K., Tian, L., et al. 2018. Birds in the Himalayas: What drives beta diversity patterns along an elevational gradient? Ecology and evolution 8:11704-11716. https://doi.org/10.1002/ece3.4622

Inskipp, C., Baral, H. S., Inskipp, T., Khatiwada, A. P., Khatiwada, M. P., Poudyal, L. P., et al. 2017. Nepal's National Red List of Birds. Journal of Threatened Taxa 9:9700. https://doi.org/10.11609/jott.2855.9.1.9700-9722

Inskipp, C. and Inskipp, T. 2003. Bird conservation priorities of the Annapurna Conservation Area. Report submitted to UNEPWCMC/King Mahendra Trust for Nature Conservation / Annapurna Conservation Area Project.

Jordano, P. 1995. Angiosperm fleshy fruits and seed dispersers: a comparative analysis of adaptation and constraints in plantanimal interactions. The American Naturalist 145:163-191. https://doi.org/10.1086/285735.

Kafle, G. 2009. A review on Research and Conservation of Otters in Nepal. IUCN Otter Specialist Group Bulletin 26:32-43.

Katuwal, H. B., Basnet, K., Khanal, B., Devkota, S., Rai, S. K., Gajurel, J. P., et al. 2016. Seasonal changes in bird species and feeding guilds along elevational gradients of the Central Himalayas, Nepal. PLoS One 11:e0158362.

https://doi.org/10.1371/journal.pone.0158362

Kissling, W. D., Sekercioglu, C. H. and Jetz, W. 2012. Bird dietary guild richness across latitudes, environments and biogeographic regions. Global Ecology and Biogeography 21:328-340. https://doi.org/10.1111/j.1466-8238.2011.00679.x

Moorcroft, D., Whittingham, M., Bradbury, R. and Wilson, J. 2002. The selection of stubble fields by wintering granivorous birds reflects 
vegetation cover and food abundance. Journal of Applied Ecology 535-547.

https://doi.org/10.1046/j.1365-2664.2002.00730.x

Munson, M. A., Caruana, R., Fink, D., Hochachka, W. M., Iliff, M., Rosenberg, K. V., et al. 2010. A method for measuring the relative information content of data from different monitoring protocols. Methods in Ecology and Evolution 1:263-273. https://doi.org/10.1111/j.2041-210X.2010.00035.x

Naish, D. 2014. The fossil record of bird behaviour. Journal of Zoology 292:268-280. https://doi.org/10.1111/jzo.12113

Newton, I. 2003. Speciation and biogeography of birds. Academic Press, USA, p 656.

Olson, D. M. and Dinerstein, E. 2002. The Global 200: Priority ecoregions for global conservation. Annals of the Missouri Botanical Garden 199-224. https://doi.org/10.2307/3298564

Pan, X., Ding, Z., Hu, Y., Liang, J., Wu, Y., Si, X., et al. 2016. Elevational pattern of bird species richness and its causes along a central Himalaya gradient, China. PeerJ 4:e2636. https://doi.org/10.7717/peerj.2636

Pandey, N., Khanal, L. and Chalise, M. K. 2020. Correlates of avifaunal diversity along the elevational gradient of Mardi Himal in Annapurna Conservation Area, Central Nepal. Avian Research 11. https://doi.org/10.1186/s40657-020-00217-6

Pavlacky Jr, D. C., Possingham, H. P. and Goldizen, A. W. 2015. Integrating life history traits and forest structure to evaluate the vulnerability of rainforest birds along gradients of deforestation and fragmentation in eastern Australia. Biological Conservation 188:89-99. https://doi.org/10.1016/j.biocon.2014.10.020

Reijnen, R., Foppen, R., Braak, C. T. and Thissen, J. 1995. The effects of car traffic on breeding bird populations in woodland. III. Reduction of density in relation to the proximity of main roads. Journal of Applied Ecology 187-202.

https://doi.org/10.2307/2404428

Schaub, M., Martinez, N., Tagmann-loset, A., Weisshaupt, N., Maurer, M. L., Reichlin, T. S., et al. 2010. Patches of bare ground as a staple commodity for declining ground-foraging insectivorous farmland birds. PLoS One 5:e13115. https://doi.org/10.1371/journal.pone.0013115

Seavy, N. 2006. Physiological correlates of habitat association in East African sunbirds (Nectariniidae). Journal of Zoology 270:290297. https://doi.org/10.1111/j.1469-7998.2006.00138.x

Sekercioglu, C. H. 2002. Effects of forestry practices on vegetation structure and bird community of Kibale National Park, Uganda. Biological Conservation 107:229-240. https://doi.org/10.1016/S0006-3207(02)00097-6
Sekercioglu, Ç. H., Daily, G. C. and Ehrlich, P. R. 2004. Ecosystem consequences of bird declines. Proceedings of the National Academy of Sciences 101:18042-18047. https://doi.org/10.1073/pnas.0408049101.

Sereno, P. C. and Chenggang, R. 1992. Early evolution of avian flight and perching: new evidence from the Lower Cretaceous of China. Science 255:845-848.

https://doi.org/10.1126/science.255.5046.845

Shrestha, T. K., Aryal, A., Rai, R. K., Lamsal, R. P., Koirala, S., Jnawali, D., et al. 2014. Balancing wildlife and human needs: the protected forest approach in Nepal. Natural Areas Journal 34:376-380. https://doi.org/10.3375/043.034.0313

Sundar, K. G. and Subramanya, S. 2010. Bird use of rice fields in the Indian subcontinent. Waterbirds 33:44-70. https://doi.org/10.1675/063.033.s104

Symes, W. S., Edwards, D. P., Miettinen, J., Rheindt, F. E. and Carrasco, L. R. 2018. Combined impacts of deforestation and wildlife trade on tropical biodiversity are severely underestimated. Nature communications 9:1-9. https://doi.org/10.1038/s41467-018-06579-2

Taylor, P. D., Fahrig, L., Henein, K. and Merriam, G. 1993. Connectivity is a vital element of landscape structure. Oikos 68(3):571-573. https://doi.org/10.2307/3544927

Vallecillo, S., Maes, J., Polce, C. and Lavalle, C. 2016. A habitat quality indicator for common birds in Europe based on species distribution models. Ecological Indicators 69:488-499. https://doi.org/10.1016/j.ecolind.2016.05.008

Walker, J. and Taylor, P. 2017. Using eBird data to model population change of migratory bird species. Avian Conservation and Ecology 12. https://doi.org/10.5751/ACE-00960-120104

White, R. L. and Bennett, P. M. 2015. Elevational distribution and extinction risk in birds. PLoS One 10:e0121849. https://doi.org/10.1371/journal.pone.0121849

Wilson, E. O. 1989. Conservation: the next hundred years. Conservation for the Twenty-first Century, pp 3-7.

Wunderle Jr, J. M. and Waide, R. B. 1993. Distribution of overwintering Nearctic migrants in the Bahamas and Greater Antilles. The Condor 95:904-933. https://doi.org/10.2307/1369428

Cite this article as:

Dangaura, H. L., Pandey, N., Chand, D. B. and Bhusal, K. P. 2020. Avian richness of the Basanta Protected Forest, far-western lowland Nepal: Implication for conservation. Nepalese Journal of Zoology 4(2):68-84. https://doi.org/10.3126/njz.v4i2.33886 
Annex 1: List of bird species from Basanta forest and their taxonomic position, feeding guild category and conservation priority.

Note: GTC: Globally Threatened Category, NTC: Nationally Threatened Category, CITES: Convention on International Trade in Endangered Species of Wild Fauna and Flora (O: Omnivores, H: Herbivores, I: Insectivores, P: Piscivores, G: Granivores, C: Carnivores, F: Frugivores)

\begin{tabular}{|c|c|c|c|c|c|c|}
\hline SN & Order & Family & English name & Scientific name & $\begin{array}{l}\text { Feeding } \\
\text { Guilds }\end{array}$ & $\begin{array}{l}\text { GTC/NTCI } \\
\text { CITES }\end{array}$ \\
\hline 1 & Galliformes & Phasianidae & hill partridge & Arborophila torqueola & $\mathrm{O}$ & \\
\hline 2 & Galliformes & Phasianidae & common quail & Coturnix coturnix & $\mathrm{O}$ & \\
\hline 3 & Galliformes & Phasianidae & rain quail & Coturnix coromandelica & $\mathrm{O}$ & \\
\hline 4 & Galliformes & Phasianidae & black francolin & Francolinus francolinus & $\mathrm{O}$ & \\
\hline 5 & Galliformes & Phasianidae & grey francolin & Francolinus pondicerianus & $\mathrm{O}$ & ../VU/.. \\
\hline 6 & Galliformes & Phasianidae & swamp francolin & Francolinus gularis & $\mathrm{O}$ & VU/EN/.. \\
\hline 7 & Galliformes & Phasianidae & Indian peafowl & Pavo cristatus & $\mathrm{O}$ & ...../III \\
\hline 8 & Galliformes & Phasianidae & red junglefowl & Gallus gallus & $\mathrm{O}$ & \\
\hline 9 & Galliformes & Phasianidae & kalij pheasant & Lophura leucomelanos & $\mathrm{O}$ & ../../III \\
\hline 11 & Anseriformes & Anatidae & greylag goose & Anser anser & $\mathrm{H}$ & \\
\hline 12 & Anseriformes & Anatidae & goosander & Mergus merganser & $\mathrm{P}$ & \\
\hline 13 & Anseriformes & Anatidae & ruddy shelduck & Tadorna ferruginea & $\mathrm{H}$ & \\
\hline 14 & Anseriformes & Anatidae & common shelduck & Tadorna tadorna & I & \\
\hline 15 & Anseriformes & Anatidae & African comb duck & Sarkidiornis melanotos & $\mathrm{H}$ & ../EN/II \\
\hline 16 & Anseriformes & Anatidae & cotton pygmy-goose & Nettapus coromandelianus & $\mathrm{H}$ & ...VU/.. \\
\hline 17 & Anseriformes & Anatidae & red-crested pochard & Netta rufina & $\mathrm{H}$ & \\
\hline 18 & Anseriformes & Anatidae & common pochard & Aythya ferina & $\mathrm{O}$ & VU/../.. \\
\hline 19 & Anseriformes & Anatidae & ferruginous duck & Aythya nyroca & $\mathrm{O}$ & ../VU/.. \\
\hline 20 & Anseriformes & Anatidae & tufted duck & Aythya fuligula & C & \\
\hline 23 & Anseriformes & Anatidae & falcated duck & Mareca falcata & $\mathrm{H}$ & ../CR/.. \\
\hline 24 & Anseriformes & Anatidae & gadwall & Mareca strepera & $\mathrm{H}$ & \\
\hline 25 & Anseriformes & Anatidae & Eurasian wigeon & Anas penelope & $\mathrm{H}$ & \\
\hline 26 & Anseriformes & Anatidae & Indian spot-billed duck & Anas poecilorhyncha & $\mathrm{O}$ & \\
\hline 27 & Anseriformes & Anatidae & mallard & Anas platyrhynchos & $\mathrm{O}$ & \\
\hline 28 & Anseriformes & Anatidae & northern pintail & Anas acuta & $\mathrm{O}$ & ../EN/.. \\
\hline 29 & Anseriformes & Anatidae & common teal & Anas crecca & $\mathrm{O}$ & \\
\hline 30 & Podicipediformes & Podicipedidae & little grebe & Tachybaptus ruficollis & $\mathrm{P}$ & \\
\hline 31 & Podicipediformes & Podicipedidae & great crested grebe & Podiceps cristatus & $\mathrm{P}$ & \\
\hline 32 & Columbiformes & Columbidae & rock dove & Columba livia & G & \\
\hline 33 & Columbiformes & Columbidae & Oriental turtle-dove & Streptopelia orientalis & G & \\
\hline 34 & Columbiformes & Columbidae & Eurasian collared-dove & Streptopelia decaocto & G & \\
\hline 35 & Columbiformes & Columbidae & red turtle-dove & Streptopelia tranquebarica & G & \\
\hline 36 & Columbiformes & Columbidae & western spotted dove & Spilopelia suratensis & G & \\
\hline 37 & Columbiformes & Columbidae & grey-capped emerald dove & Chalcophaps indica & G & \\
\hline 38 & Columbiformes & Columbidae & orange-breasted green-pigeon & Treron bicinctus & $\mathrm{F}$ & \\
\hline
\end{tabular}




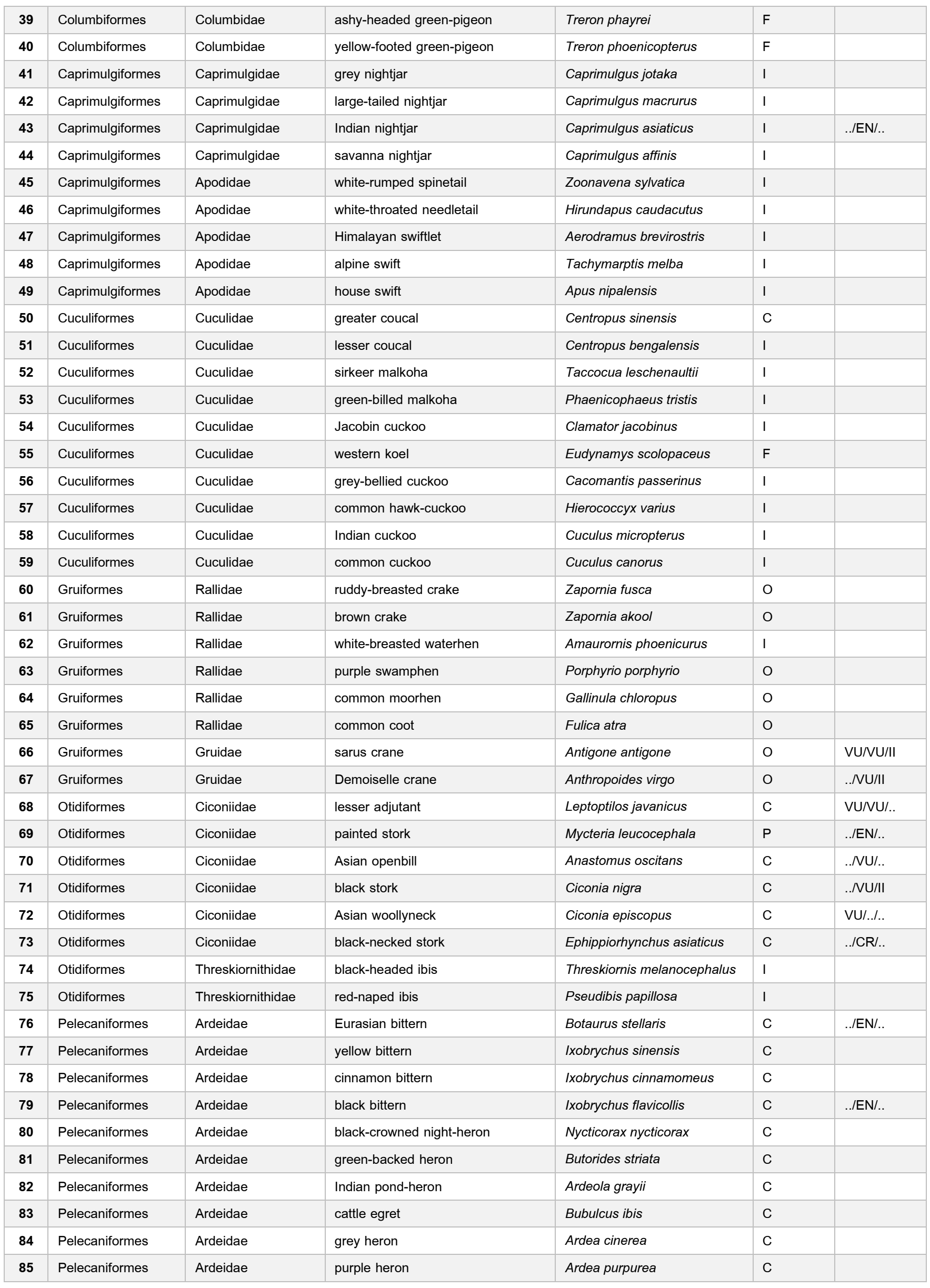




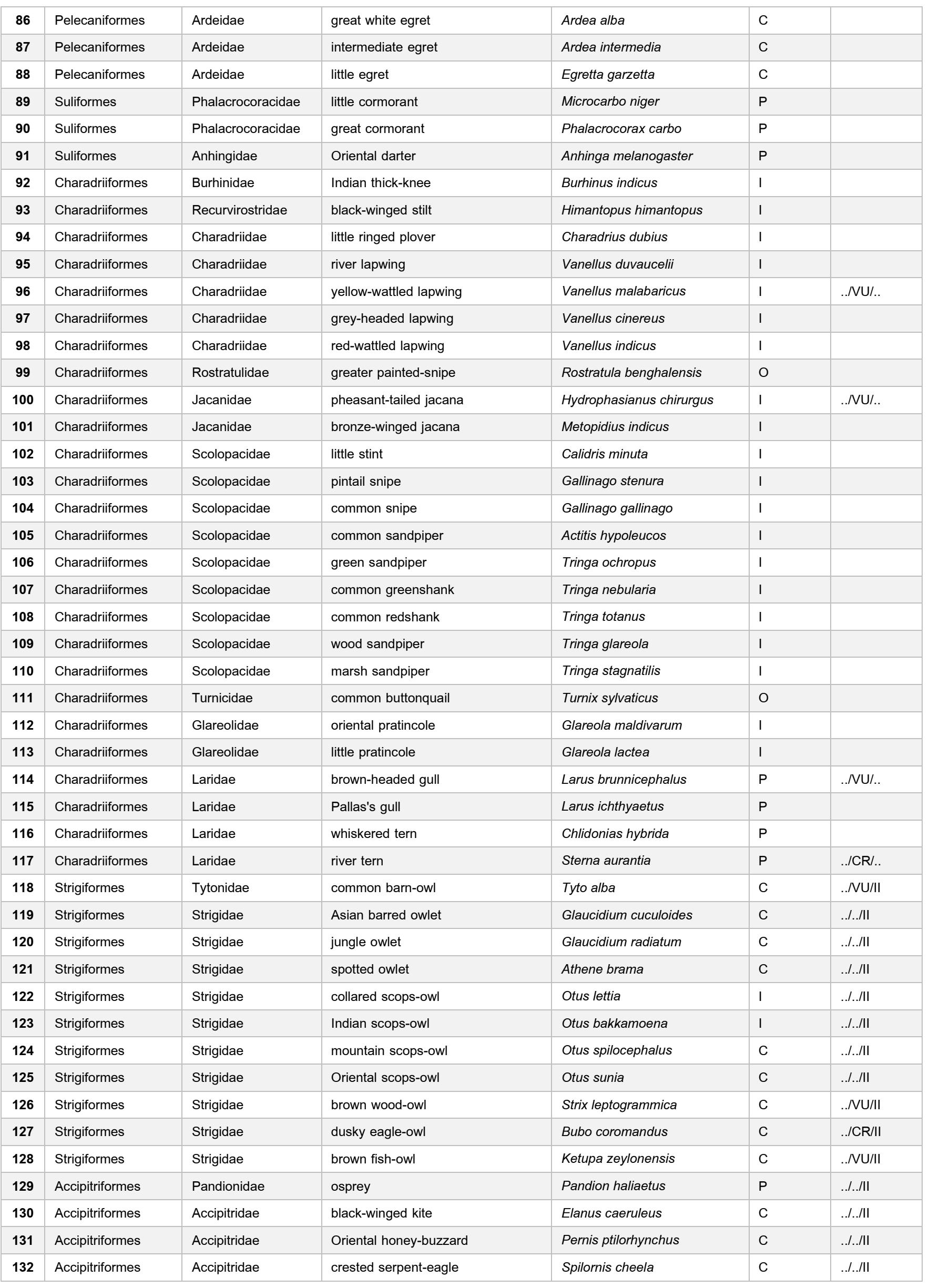




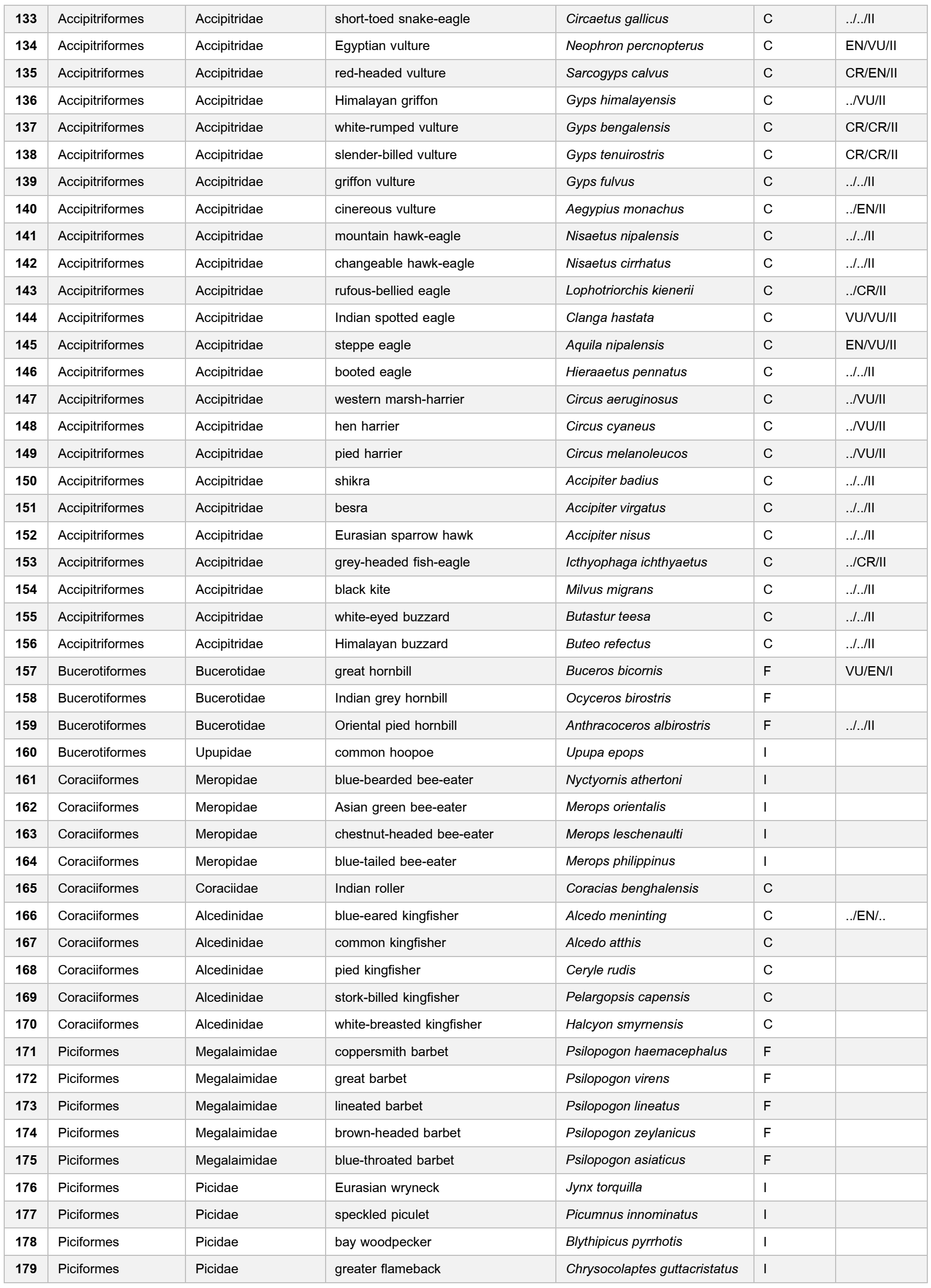




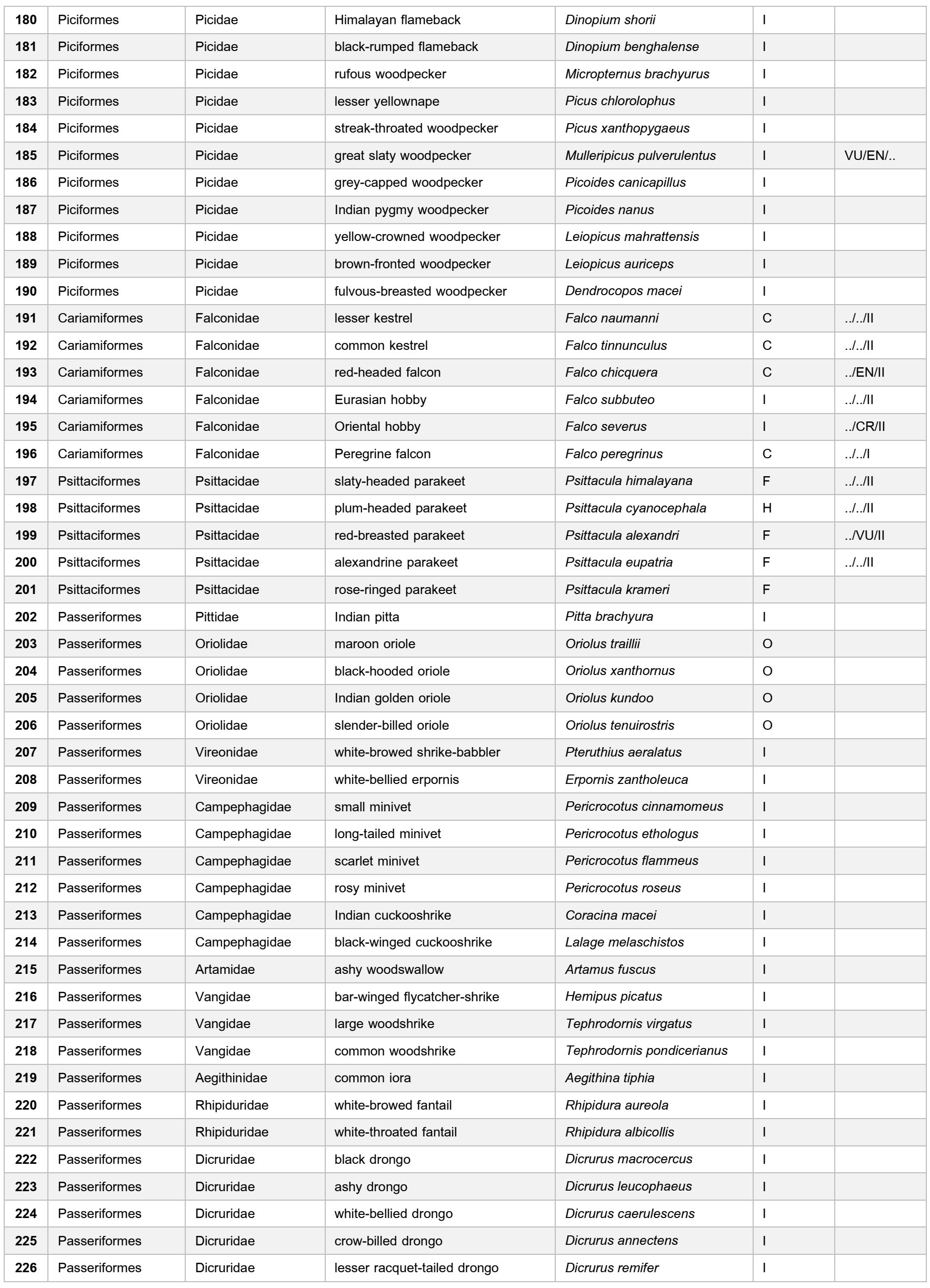




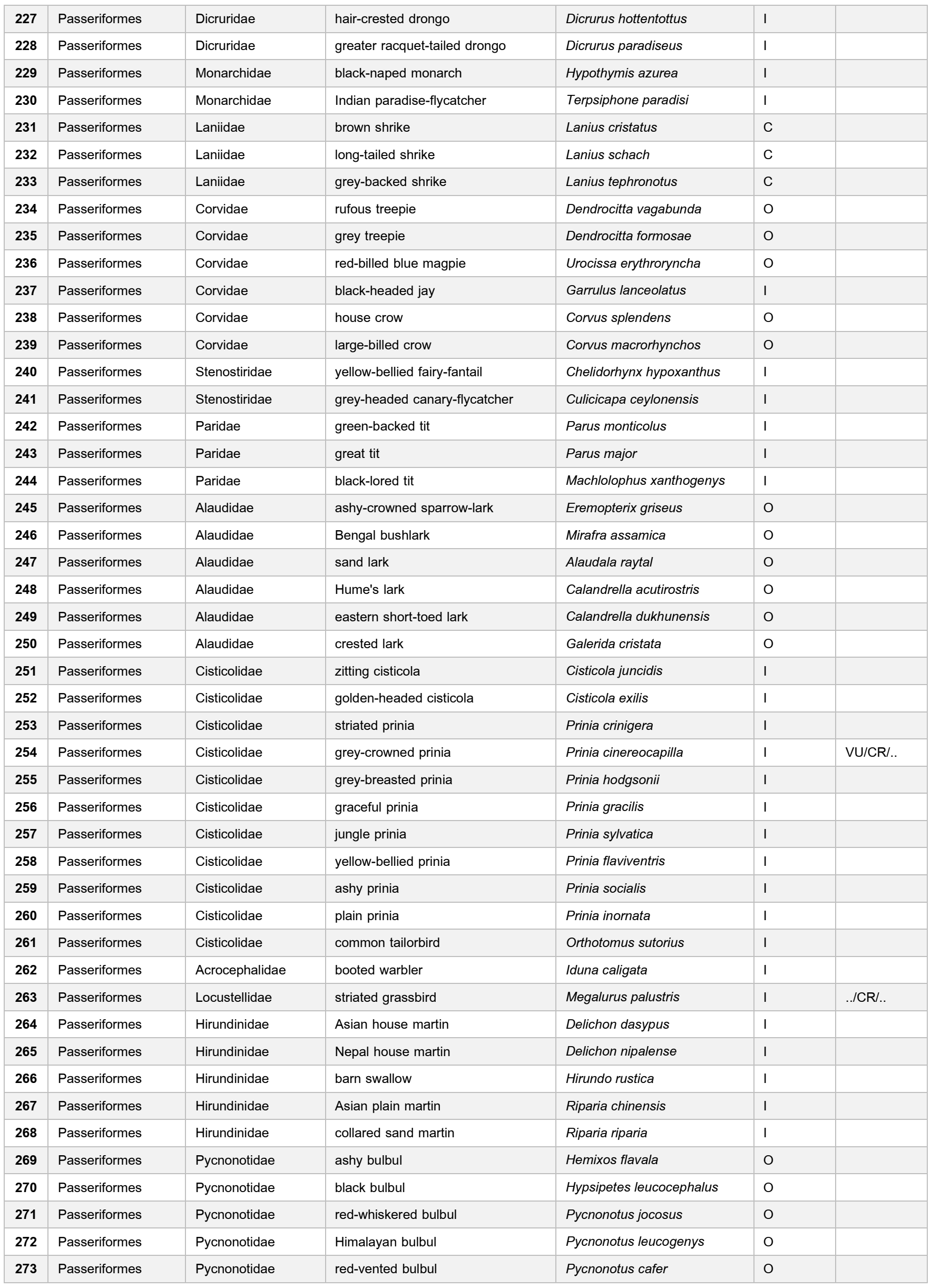




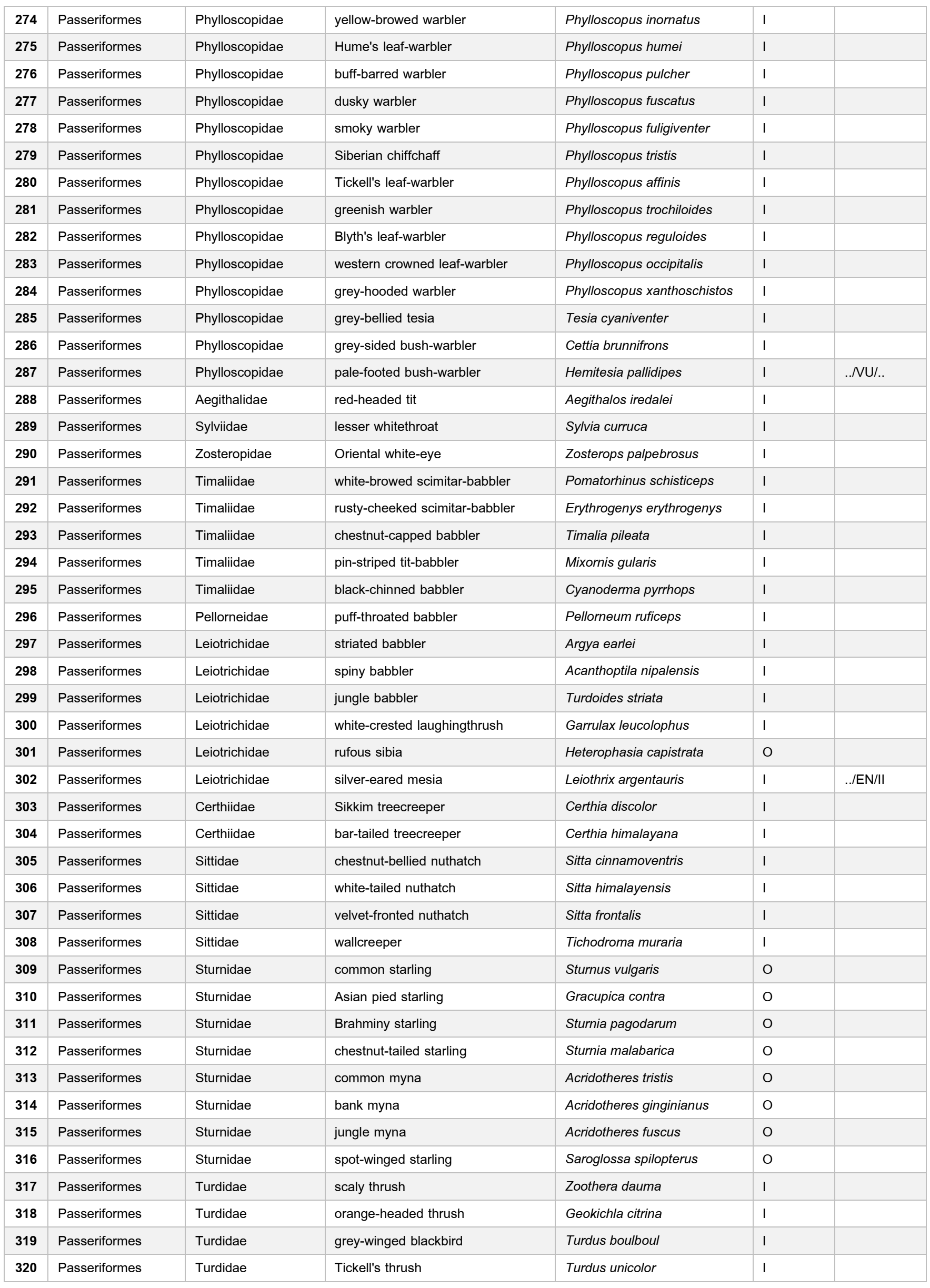




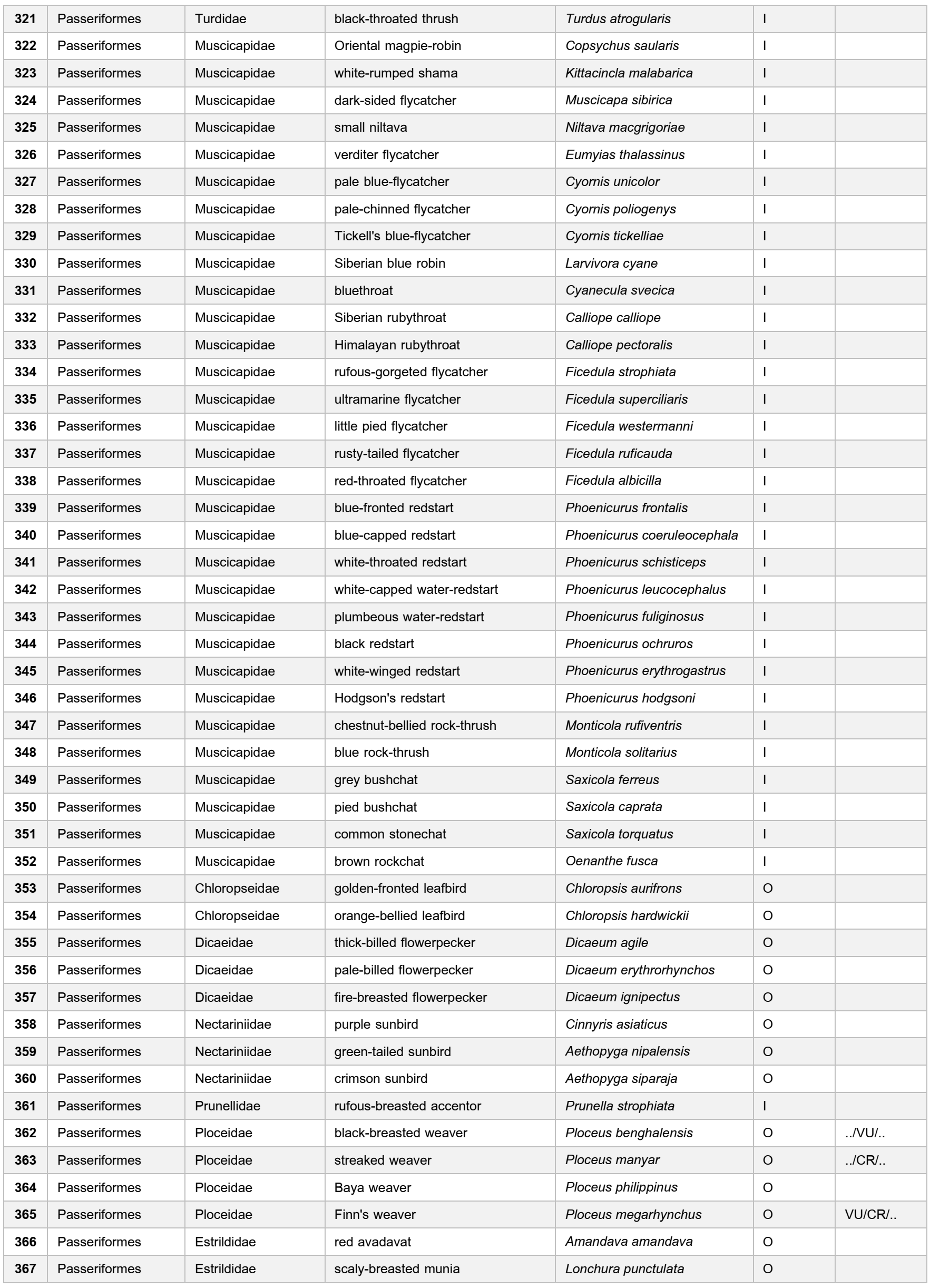




\begin{tabular}{|c|c|c|c|c|c|c|}
\hline 368 & Passeriformes & Estrildidae & tricoloured munia & Lonchura malacca & $\mathrm{O}$ & \\
\hline 369 & Passeriformes & Passeridae & house sparrow & Passer domesticus & $\mathrm{O}$ & \\
\hline 370 & Passeriformes & Passeridae & Eurasian tree sparrow & Passer montanus & $\mathrm{O}$ & \\
\hline 371 & Passeriformes & Passeridae & chestnut-shouldered bush-sparrow & Gymnoris xanthocollis & $\mathrm{O}$ & \\
\hline 372 & Passeriformes & Motacillidae & olive-backed pipit & Anthus hodgsoni & 1 & \\
\hline 373 & Passeriformes & Motacillidae & paddyfield pipit & Anthus rufulus & 1 & \\
\hline 374 & Passeriformes & Motacillidae & western yellow wagtail & Motacilla flava & 1 & \\
\hline 375 & Passeriformes & Motacillidae & grey wagtail & Motacilla cinerea & 1 & \\
\hline 376 & Passeriformes & Motacillidae & citrine wagtail & Motacilla citreola & I & \\
\hline 377 & Passeriformes & Motacillidae & white-browed wagtail & Motacilla maderaspatensis & I & \\
\hline 378 & Passeriformes & Motacillidae & white wagtail & Motacilla alba & 1 & \\
\hline 380 & Passeriformes & Emberizidae & crested bunting & Emberiza lathami & $\mathrm{O}$ & \\
\hline 381 & Passeriformes & Emberizidae & black-faced bunting & Emberiza spodocephala & $\mathrm{O}$ & $. . . \mathrm{VU} / .$. \\
\hline
\end{tabular}

